\title{
MANAJEMEN PENDIDIKAN DI SMK MA'ARIF 4 KEBUMEN
}

\author{
Bahrun Ali Murtopo \\ IAINU Kebumen \\ bahrunalimurtopo@gmail.com \\ Mahasiswa MPI IAINU Kebumen \\ Syifa Maulana, Nunung Nurngaeni, Durotul Ngaesi, Purwatiningsih, Avianti Kurniasari, Nayla \\ Maghfiroh, Umi Sifah \\ syifagletux@gmail.com
}

\begin{abstract}
Abstrak :
Penelitian kolaboratif dosen mahasiswa ini dilakukan untuk mengetahui manajemen pendidikan di sebuah lembaga pendidikan sekolah menengah kejuruan. Lokasi penelitian di SMK Ma'arif 4 Kebumen. Penelitian ini bersifat kualitatif dengan teknik pengumpulan data wawancara, observasi dan dokumentasi. Penelitian ini dilakukan Juli-Agustus 2019. Informan penelitian adalah Kepala SMK Maarif 4 Kebumen dan sejumlah guru dan staf terkait focus penelitian. Hasil penelitian ini adalah bahwa: (1)manajemen kurikulum dan pembelajaran, manajemen peserta didik dan bimbingan konseling, manajemen pendidik dan tenaga kependidikan, dan manajemen hubungan industri kesemuanya sudah cukup baik, walaupun perlu pengembangan, inovasi, dan kreasi. Rekomendasi, manajemen pendidikan di lokasi penelitian masih perlu penguatan lagi untuk mampu menjawab kebutuhan perkembangan zaman.
\end{abstract}

\section{Kata Kunci: Manajemen Pendidikan, Kepemimpinan.}

\section{A. Pendahuluan}

Manajemen pendidikan merupakan serangkaian kegiatan saling terkait yang meliputi proses perencanaan, pengorganisasian, dan pengendalian dalam mencapai tujuan yang sudah ditetapkan, serta melibatkan orang dan sumber daya organisasi lainnya. Manajemen sangatlah penting, karena segala keberhasilan yang dicapai tergantung pada manajemennya, seperti yang diungkapkan oleh Deming (Sallis, 2007: 97),"masalah mutu terletak pada masalah manajemennya." Tujuan dari manajemen pendidikan adalah sebagai tolak ukur dan untuk mempermudah proses dalam mencapai tujuan pendidikan. Sufyarma (2004:190), mengemukakan 
bahwa, "manajemen berperan untuk memberdayakan berbagai komponen pendidikan", semakin baik manajemennya maka semakin baik pula kualitas pendidikannya. ${ }^{1}$

Jadi manajemen pendidikan merupakan tolak ukur dalam dunia pendidikan baik atau tidaknya mutu sebuah pendidikan, semua tergantung pada bagaimana manajemennya. Banyaknya permasalahan dalam manajemen pendidikan disebabkan karena kurang tepatnya sasaran dan kebijakan yang diambil oleh seorang manajer dalam sebuah lembaga pendidikan. Untuk itu kepala sekolah berperan penting dalam meningkatkan kualitas pendidikan disekolah yang ia kelola, karena kepala sekolah merupakan leader yang mana akan membawa keberhasilan maupun kegagalan dari madrasah yang ia kelola.

Di dalam lembaga pendidikan, menjadi kepala sekolah bukan perkara yang mudah, bukan pula perkara yang sulit. Namun ketika mengenal, memahami, meyakini cara menjadi kepala sekolah yang handal, maka hal yang niscaya melaksanakan tugas mulia menjadi seorang kepala sekolah akan terwujud dan akan lebih mudah. ${ }^{2}$ Sebaliknya, ketika seorang kepala sekolah tidak mengenal, memahami menjadi kepala sekolah, meyakini menjadi kepala sekolah, maka dalam melaksanakan tugasnya pun akan menjadi beban dan kesulitan. Selain mengenal, memahami, dan meyakini menjadi kepala sekolah, kepala sekolah juga harus mampu berperilaku bersahabat dengan seluruh warga sekolah yang ia kelola, kepala sekolah harus mampu mendorong, mengarahkan, dan memotivasi seluruh warga sekolah untuk bekerja sama dalam mewujudkan visi, misi, dan tujuan sekolah yang di kelola. Dengan adanya sikap yang bersahabat dengan seluruh warga sekolah tersebut maka dalam mengembangkan sekolahnya pun akan lebih kondusif, efektif dan efisien. Menurut 'Stogdill kepemimpinan merupakan proses mempengaruhi kegiatan kegiatan suatu kelompok yang diorganisasi, menuju kepada penentuan /pencapaian tujuan'. 3 Dari pendapat di tersebut terlihat bahwa kepemimpinan sangat mempengaruhi suatu organisasi, tercapai atau tidaknya perencanaan yang telah di tetapkan tersebut tergantung dari cara pemimpin tersebut mengelola. Pendapat lain yang di kemukakan oleh "Arifin mengatakan bahwa kepemimpinan mempunyai peranan sentral dalam dinamika kehidupan organisasi’, 4

\footnotetext{
${ }^{1}$ Eliyanto.Manajemen Sumber Daya Manusia Pendidikan.(Yogyakarta: Program Studi Manajemen Pendidikan Islam Fakultas Ilmu Tarbiyah dan Keguruan Universitas Islam Negeri (UIN) Sunan Kalijaga.2018). hal . 44.

${ }^{2}$ Djafri Novianty. Manajemen Kepemimpinan Kepala Sekolah (Yogyakarta : CV Budi Utama, 2017 ) hlm, 1

${ }^{3}$ Daryanto. Kepala Sekolah sebagai Pemimpin Pembelajaran (Yogyakarta : Gava media, 2011) hlm 17

${ }^{4}$ Hermino Agustinus. Kepemimpinan Pendidikan di Era Globalisasi (Yogyakarta : Pustaka Pelajar, 2014) hlm 17
} 
Di dalam lembaga pendidikan, kinerja kepemimpinan kepala sekolah sangat berpengaruh terhadap pengembangan pendidikan yang ia kelola, sudah seharusnya seorang pemimpin pendidikan harus mampu mengimplementasikan manajemen sekolah demi mewujudkan tujuan pendidikan secara efektif, efisien, produktif, dan akuntabel. Oleh sebab itu kepala sekolah memiliki peran yang sangat penting dalam mengembangkan manajemen sekolah supaya dapat berjalan dengan visi, misi, tujuan, tuntutan masyarakat serta tuntutan zaman yang semakin pesat, bukan hanya mengimplementasikan manajemen sekolah saja, tetapi seorang pemimpin sekolah juga harus mempunyai keahlian yang lengkap layaknya seorang pengelola pendidikan. Dalam konteks ini kepemimpin sekolah harus mampu memfungsikan peranya secara maksimal dan mampu memimpin sekolahnya dengan bijak, tetarah, serta mengarah pada pencapaian tujuan pendidikan yang maksimal demi mengembangkan pendidikan di sekolah yang dikelola.

Namun tidak dapat dipungkiri bahwa, dari pemaparan di atas sangat bertolak belakang dengan realita yang tejadi saat ini, minimnya kesadaran masyarakat dalam memilih pemimpin yang kompeten menyebabkan sulitnya menemukan sosok pemimpin yang ideal yang memiliki komitmen tinggi terhadap tugas dan tanggung jawabnya. Dalam realita yang terjadi banyaknya masyarakat yang memilih pemimpin hanya berdasarkan latar belakang, kerabat, dan sebagainya, sehingga banyak di temui pemimpin pemimpin yang sebenarnya kurang layak dalam mengemban amanah kepemimpinanya. 'Demikian halnya di dalam pendidikan, tidak sedikit pemimpin pemimpin pendidikan yang tidak memiliki visi, misi dan tujuan yang jelas dalam mengelola sekolah yang di pimpinya", 5 Keadaan yang seperti itulah yang mengakibatkan buruknya iklim dan budaya di sekolah. dari konflik di atas tentunya sangat tidak lazim apabila budaya tersebut terus di lakukan, hal tersebut tentu saja harus ada penanganan yang serius, karena seorang pemimpin pendidikan akan membawa dampak baik atau buruknya sekolah yang di kelola.

Penelitian ini bertujuan mengetahui bagaimana manajemen pendidikan di SMK Maarif 4 Kebumen, khususnya terkait dengan empat manajemen (kurikulum pembelajaran, kesiswaan dan bimbingan konseling, pendidik dan tenaga kependidikan, dan hubungan industry), dan sekaligus model kepemimpinan yang berlangsung di lokasi penelitian. Penelitian bersifat kualitatif dengan mempergunakan teknik pengumpulan data wawancara, observasi, dan dokumentasi. Penelitian berlangsung Juli- Agustus 2019 dalam kemasan kegiatan praktek latihan profesi (PLP).

\footnotetext{
${ }^{5}$ Mulyasa, Manajemen Kepemimpinan Kepala Sekolah (Jakarta: PT Bumi Aksara, 2015) hlm 17
} 


\section{B. Hasil Penelitian dan Pembahasan}

Pada awalnya, sekolah ini bernama STM Ma'arif 4 yang didirikan di Desa Mangunranan, Kecamatan Mirit, Kabupaten Kebumen dengan surat izin operasional No. 632/1010/I/96 dari Kanwil Departemen Pendidikan dan Kebudayaan pada tahun ajaran 1996/1997 dengan jurusan teknik mesin dan menempati ruangan MTs Ma’arif Mangunranan.

Pada tahun pelajaran 1997/1998 sekolah pindah ke Kebumen menempati gedung NU dan diberi nama STM Ma'arif 4 Kebumen. Pada tahun 1998 STM Ma'arif 4 Kebumen pindah ke gedung sebelah selatan toko kramik Jl. Kusuma No. 76 Kebumen. Pada 1999 STM Ma'arif 4 Kebumen menempati gedung baru di Jl. Aroengbinang No. 25 Kebumen sampai sekarang.

Diberlakukannya kurikulum edisi 1999 (kurikulum 2004 yang disempurnakan), maka STM Ma'arif 4 Kebumen berubah menjadi SMK Ma'arif 4 Kebumen. Adapun program keahlian yang dimiliki oleh SMK Maarif 4 Kebumen adalah sebagai berikut :

a. Teknik audio vidio

b. Teknik mesin industri

c. Teknik kendaraan ringan

d. Perbankan syariah

e. pariwisata

Sebagai wujud peningkatan mutu dan layanan mulai tahun 2012 SMK Ma'arif 4 Kebumen menerapkan dan bersertifikasi SMM ISO 9001:2008 yaitu sebuah lembaga penjamin mutu internasional dari Jerman. ${ }^{6}$ SMK Ma'arif 4 Kebumen adalah Sekolah Menengah Kejuruan swasta dibawah naungan LP Ma'arif NU Cabang Kebumen yang terletak di Jl. Aroengbinang No. 25 Kebumen.

\section{a. Visi, Misi Dan Tujuan}

Sekolah menengah kejuruan ma'arif 4 kebumen mempunyai visi : "Teguh Dalam Imtaq, Unggul Dalam Prestasi Dan Berakhlak Mulia."

Misi 
- Menumbuh kembangkan pengalaman nilai-nilai agama islam

- Melaksanakan bimbingan dengan mengedepankan uswatun khasanah

- Memotivasi secara intensif dalam mewujudkan keunggulan

- Menerapkan dan menguatkan keterlibatan stakeholder dalam manajemen sekolah

- Melaksanakan pembelajaran secara efektif dan efisien

- Mendorong dan membantu peserta didik untuk mengerti terhadap potensi yang dimilikinya

- Melestarikan budaya baik dan inovatif terhadap budaya baru yang lebih baik

- Menumbuh kembangkan sikap akhlakul karimah.

Tujuan Pendidikan SMK Ma'arif 4 yaitu:

a. Menyiapkan siswa untuk memasuki lapangan kerja serta mengembangkan sikap profesional.

b. Menyiapkan siswa agar mampu memilih karier, mampu berkompetensi dan mampu mengembangkan diri.

c. Menyiapkan tenaga kerja tingkat menengah untuk memenuhi kebutuhan dunia usaha dan industri pada saat ini maupun yang akan datang.

d. Menyiapkan tamatan agar menjadi warga negara yang taqwa, kreatif berakhlaqul karimah serta mampu berwirausaha.

Struktur Organisasi dan Kepemimpinan di SMK Ma'arif 4 Kebumen

$\begin{array}{ll}\text { Kepala Sekolah } & \text { : Solikhudin, S. Pt, S. Pd } \\ \text { Waka Kurikulum } & : \text { Nur Khotib, ST } \\ \text { Waka Kesiswaan } & : \text { M. Fatkhul Amali, S. Pd } \\ \text { Waka Ketenagaan } & : \text { H. Muhamad Kowangid, M.Pd } \\ \text { Waka Hub. Industri } & : \text { Drs. Fatnan Sugiarto } \\ \text { Kajur TKR } & : \text { Aris Murdianto S. Pd } \\ \text { Kajur TAV } & : \text { Wisnu Wijaya, ST } \\ \text { Kajur TPMI } & : \text { Doni Rohmiyanto, S. Pd }\end{array}$


Kajur Perbankan Syariah

Kajur Usaha Perjalanan Wisata

Kepala TU

Koordinator BK

Koordinator Lab. kom.

Koordinator lab bahasa
: Bintang Putra Nugraha S.Kom

$:-$

: Agus Nawawi, S.Pd.I

: Fifi Alfiyatun, S. Pd

: Bambang Hermanto, S.E.

: Anwar Mustofa, S.Pd.

Di dalam lembaga pendidikan tanggung jawab yang paling besar adalah posisi yang ada pada kepala sekolah sebagai seorang pemimpin dengan peran kepemimpinanya. Ia merupakan factor yang dapat mempengaruhi gagal atau berhasilnya sebuah lembaga. Dengan kata lain berhasil tidaknya sebuah lembaga pendidikan di pengaruhi oleh factor kepemimpinanya.7

Dari pemaparan tersebut dapat di lihat bahwa menjadi kepala sekolah bukan perkara yang mudah, bukan pula perkara yang sulit. Namun ketika mengenal, memahami, meyakini cara menjadi kepala sekolah yang handal, maka hal yang niscaya melaksanakan tugas mulia menjadi seorang kepala sekolah akan terwujud dan akan lebih mudah. Sebaliknya, ketika seorang kepala sekolah tidak mengenal, memahami menjadi, meyakini menjadi kepala sekolah, maka dalam melaksanakan tugasnya pun akan menjadi beban dan kesulitan.

Selain mengenal, memahami, dan meyakini menjadi kepala sekolah, kepala sekolah juga harus mampu berperilaku bersahabat dengan seluruh warga sekolah yang ia kelola, kepala sekolah harus mampu mendorong, mengarahkan, dan memotivasi seluruh warga sekolah untuk bekerja sama dalam mewujudkan visi, misi, dan tujuan sekolah yang di kelola. Dengan adanya sikap yang bersahabat dengan seluruh warga sekolah tersebut maka dalam mengembangkan sekolahnya pun akan lebih kondusif, efektif dan efisien.

Menurut Stogdill kepemimpinan merupakan proses mempengaruhi kegiatan kegiatan suatu kelompok yang diorganisasi, menuju kepada penentuan /pencapaian tujuan.8 Pendapat lain yang di kemukakan oleh Arifin mengatakan bahwa kepemimpinan mempunyai peranan sentral dalam dinamika kehidupan organisasi.9

\footnotetext{
${ }^{7}$ Muwahid., Model Kepemimpinan Kepala Madrasah, ( Yogyakarta : Teras, 2013), hlm. 2.

${ }^{8}$ Daryanto, Kepala Sekolah sebagai Pemimpin Pembelajaran, (Yogyakarta : Gava media, 2011), hlm. 17.

${ }^{9}$ Hermino Agustinus, Kepemimpinan Pendidikan di Era Globalisasi, (Yogyakarta : Pustaka Pelajar, 2014), hlm. 17.
} 
Dari pendapat beberapa ahli di atas, dapat di simpulkan bahwa kepemimpinan sangat berpengaruh terhadap dampak kualitas dan pengembangan pendidikan yang ia kelola, baik buruknya lembaga pendidikan, tergantung bagaimana cara kepala sekolah dalam mengelola sekolahnya.

Dari setiap gaya kepemimpinan tersebut memiliki kekurangan dan kelebihan masing masing, adapun gaya kepemimpinan kepala sekolah SMK Ma'arif 4 kebumen menerapkan gaya kepemimpinan demokratis dimana kepala sekolah menerima pendapat dan saran dari bawahan dan juga kritik yang membangun dari anggota di terimanya sebagai umpan balik atau di jadikan bahan pertimbangan kesanggupan dan kemauan kelompoknya.

Bapak Solikhudin, S. Pt, S. Pd menjabat sebagai kepala sekolah selama 2 periode, dalam pemilihan kepala sekolah di tunjuk langsung dari yayasan komite LP Ma'arif NU, beliau di percaya sehingga kembali menjabat hingga 2 periode (1 Januari 2014 dan 1 Januari 2018). Dalam menjalankan tugasnya pasti terdapat faktor penghambat yaitu seperti SDM yang kurang mendukung, persaingan yang semakin ketat, kurangnya komitmen bawahan dalam menjalankan tugasnya, dan kurangnya kedisiplinan. Namun hal tersebut tidak menjadikan beban berat bagi kepala sekolah, beliau mengatakan bahwa dalam menjalankan tugasnya didasari karena amanah dari Yayasan serta diniati beribadah bukan semata mata hanya gila jabatan.

\section{b. Manajemen Kurikulum Dan Pembelajaran}

Kurikulum di SMK Ma'arif 4 Kebumen sudah disusun berdasarkan panduan kurikulum yang disusun BSNP. Kurikulum yang digunakan di SMK Ma'arif 4 Kebumen yaitu Kurikulum 2013 yang diberlakukan untuk semua kelas. Kurikulum 2013 yang telah direvisi atau yang sekarang disebut kurikulum nasional.

Dalam penyusunan kurikulum, setiap tahunnya SMK Ma'arif 4 Kebumen mengadakan workshop sebagai panduan penyusunan kurikulum yang dilaksanakan setiap awal tahun ajaran baru yang diisi oleh Pengawas Pendidikan di tingkat SMK yang di dalamnya menjelaskan perangkat kurikulum yang berlaku. Bapak Nur Khotib, ST., selaku Waksek 1 Bidang Kurikulum melibatkan kepala sekolah, wakasek 1 (bidang kurikulum), wakasek 3 (bidang ketenagaan), wakasek 4 (bidang hubin), komite dan guru dalam kegiatan workshop kurikulum tersebut. 


\section{c. Sistem Pembelajaran}

SMK Ma'arif 4 Kebumen menerapkan sistem pembelajaran moving class yaitu suatu sistem pembelajaran dimana setiap kelas ditetapkan sebagai tempat pembelajaran untuk mata pelajaran tertentu yang telah dilengkapi sarana dan prasarana yang dibutuhkan dalam proses pembelajaran. Manfaat menerapkan sistem moving class, yaitu siswa tidak merasa jenuh dalam mengikuti kegiatan belajar mengajar. Siswa merasakan suasana yang berbeda untuk setiap mata pelajaran tertentu dan peserta didik akan lebih mudah menerima pelajaran karena didalam kelas telah dilengkapi dengan fasilitas penunjang pembelajaran. Contoh Lab Fisika dan Lab Komputer.

Gambar 1. Skema Manajemen Kurikulum dan Pembelajaran SMK Ma’arif 4 Kebumen

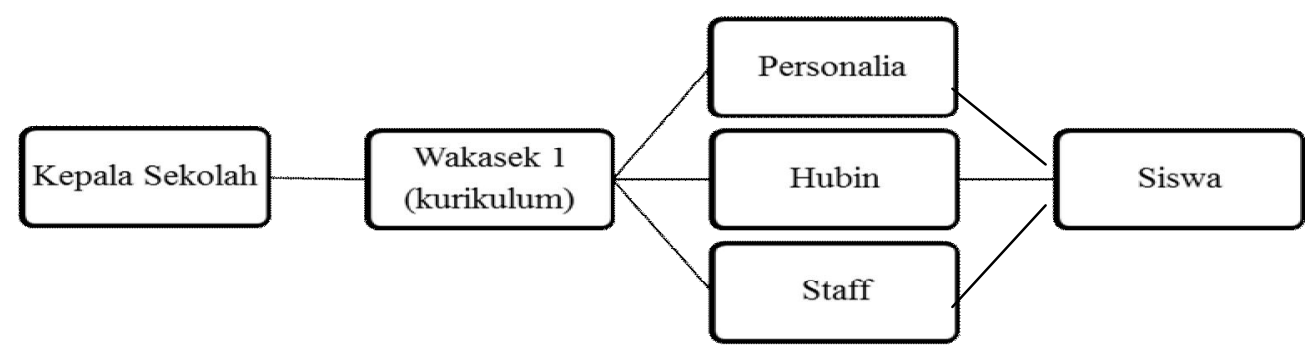

Pengelolaan kurikulum dan pembelajaran di SMK Ma'arif 4 Kebumen yaitu kepala sekolah mendelegasikan kepada wakasek 1 (bidang kurikulum), wakasek 1 (bidang kurikulum) mengkoordinasikan kepada wakasek 3 (bidang ketenagaan), wakasek 4 (bidang hubin), komite dan guru. Di SMK Ma'arif 4 Kebumen Buku dan dokumen yang diperlukan dalam bidang kurikulum dan pembelajaran yaitu visi misi \& tujuan sekolah, kalender pendidikan, silabus, ketuntasan belajar minimal (KBM), program tahunan (prota), program semester (promes), rencana pelaksanaan pembelajaran (RPP), daftar buku pegangan, sumber belajar guru dan siswa, buku agenda guru, catatan hambatan belajar siswa. 


\section{d. Faktor Pendukung Manajemen Kurikulum dan Pembelajaran}

Dalam sebuah lembaga pendidikan pasti terdapat sebuah faktor yang mendukung maupun yang menghambat. Berikut ini faktor pendukung dalam bidang kurikulum dan pembelajaran di SMK Ma'arif 4 Kebumen yaitu :

1) semua guru sudah memenuhi standar kualifikasi pendidik yaitu bergelar $S 1$,

2) terdapat $75 \%$ guru sudah bersertifikasi (sertifikat guru profesional),

3) terdapat bahan ajar yang lengkap,

4) fasilitas yang memadai dengan memiliki ruang praktek teknik untuk praktek kejuruan (TKR, Otomotif), serta memiliki 3 (tiga) ruang laboratorium komputer.

\section{e. Faktor Penghambat Manajemen Kurikulum dan Pembelajaran}

Adapun faktor penghambat dalam bidang kurikulum dan pembelajaran di SMK Ma' arif 4 Kebumen yaitu :

1) kurangnya kedisiplinan tenaga kependidikan dan pendidik begitu juga dengan peserta didik yaitu peserta didik masuk kelas tidak tepat waktu pada jam pertama.

2) adanya perubahan kurikulum 2013 (kurtilas) yang mengakibatkan adanya jam tambahan menjadikan waktu pembelajaran kurang efektif.

Dari adanya faktor penghambat dalam kurikulum pembelajaran di SMK Ma'arif 4 Kebumen Solusinya yaitu dengan adanya dispensasi waktu selama 10 menit, memberi pemahaman mengenai peraturan yang telah ditetapkan tentang waktu pembelajaran kepada peserta didik.

\section{Manajemen Kesiswaan}

Manajemen kesiswaan merupakan semua aktivitas yang berkaitan dengan siswa dari awal masuk sekolah hingga lulus sekolah dengan mengikuti peraturan dan ketertiban yang ada di sekolah. Kegiatan-kegiatan manajemen kesiswaan meliputi :

\section{a. Proses Penerimaan Calon Peserta didik}

Proses penerimaan calon Peserta didik baru merupakan agenda tahunan di SMK Ma'arif 4 Kebumen, Proses penerimaan calon peserta didik baru di SMK Ma'arif 4 Kebumen dilakukan 
dengan proses perencanaan peserta didik baru, adapun proses perencanaanya yaitu sebagai berikut:

Dalam proses penerimaan calon peserta didik baru di SMK Ma'arif 4 Kebumen dengan menggunakan cara seleksi yang meliputi tes tertulis dan tes wawancara. Untuk tes tertulis berisi tentang materi umum dan materi kejuruan sedangkan untuk tes wawancara berisi tentang alasan kenapa siswa tertarik masuk di SMK Ma'arif 4 kebumen dan menanyakan kesanggupan siswa untuk mentaati tata tertib yang ada di SMK Ma'arif 4 Kebumen. Untuk proses penerimaan calon pesera didik baru di SMK Ma' arif 4 kebumen dimulai dengan pendaftaran terlebih dahulu dengan melengkapi persyaratan yang telah di tentukan oleh sekolah

Dalam seleksi penerimaan calon peserta didik baru di SMK Ma'arif 4 Kebumen sebenarnya tidak begitu sulit, bisa dikatakan tes seleksi tersebut hanya untuk formalitas, karena SMK Ma'arif 4 Kebumen ini merupakan sekolah swasta maka dari itu tidak berkemungkinan menolak peserta didik apapun keadaanya, hampir tidak ada calon peserta didik yang tidak diterima di SMK Ma'arif 4 Kebumen dalam proses PPBD ini. Untuk peserta didik yang dinyatakan diterima maka peserta didik baru harus melakukan daftar ulang supaya dapat mengikuti tahap selanjutnya yaitu MPLS (Masa pengenalan lingkungan sekolah).

MPLS (Masa Pengenalan Lingkungan Sekolah) di SMK Ma'arif 4 Kebumen dilakukan selama tiga hari, dalam pelaksanaan orientasi peserta didik baru di SMK Ma'arif 4 Kebumen melakukan perkenalan dengan semua sumber daya manusia, semua tata tertib yang telah di tentukan baik kewajiban ataupun larangan, sarana dan parasara, dan semua kegiatan yang ada dilingkungan sekolah. Setelah MPLS selesai kegiatan selanjutnya yaitu siswa dikenalkan dengan pramuka, PMR, dan kegiatan ekstra kurikuler lainnya supaya siswa siap untuk mengikuti segala kegiatan yang ada di SMK Ma'arif 4 Kebumen.

Untuk seragam seluruhnya dibagikan pada awal masuk kecuali seragam pramuka dan dalam bersepatu di SMK Ma'arif 4 Kebumen tidak ada ketentuan khusus, yang terpenting ketika jam sekolah menggunakan sepatu

Pakaian seragam yang dibagikan oleh sekolah antara lain:

1) Pakaian seragam OSIS;

2) Pakaian seragam olahraga;

3) Pakaian seragam kejuruan 
4) Pakaian seragam identitas

5) Atribut sekolah.

Untuk ketentuan seragam sebagai berikut:

1) Hari Senin dan selasa menggunkan pakaian seragam osis, dan topi Osis

2) Hari Rabu dan kamis menggunkan pakaian seragam identitas

3) Hari Jum'at dan Sabtu menggunkan pakaian seragam pramuka.

4) Seragam kejuruan di pakai sesuai jadwal praktek

Untuk mencari data terkait peserta didik peneliti melakukan wawancara dan observasi langsung dengan Wakasek Kesiswaan di SMK Ma'arif 4 kebumen bernama M. Fathul Amali S.Pd., Bapak Perdopo sebagai staf kesiswaan dan guru BK (Fifi Alfiyatun, S. Pd dan Rosma Sukanthi, S.Pd). KTU (Agus Nawawi S.Pd.I). Adapun uraian dari hasil riset tersebut adalah :

\section{Gambar 2. Skema Manajemen Kesiswaan di SMK Ma'arif 4 Kebumen}

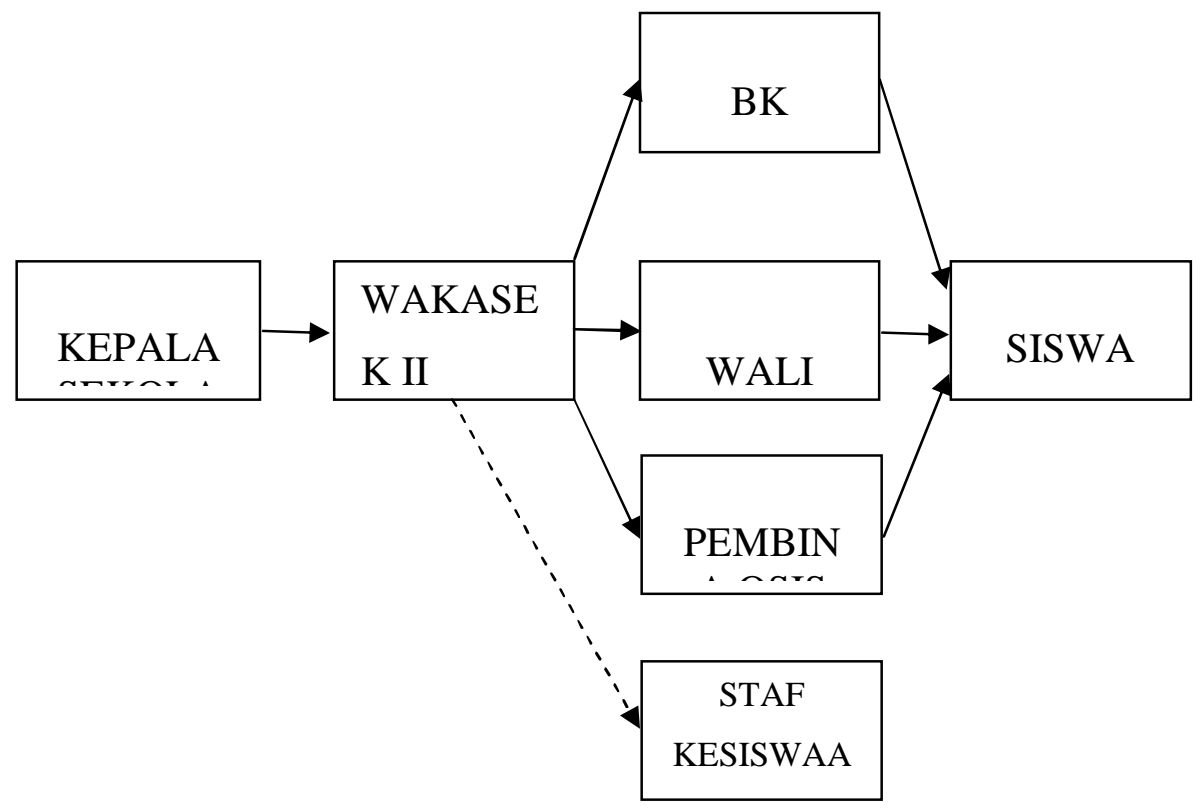

Buku dan dokumen yang diperlukan untuk melaksanakan program kerja kesiswaan :

1) Buku Tata tertib siswa 
2) Buku Daftar hadir siswa terlambat

3) Buku Laporan Absensi Siswa Harian

4) Buku Rekapitulasi Daftar Hadir Siswa Mingguan

5) Buku Rekapitulasi Daftar Hadir Siswa Bulanan

6) Untuk BK ( buku pribadi, buku hasil analisis kebutuhan siswa, AKBD, dll)

Dari hasil wawancara yang telah dilakukan pada hari Senin, 5 Agustus 2019, dalam pengelolaan di bidang kesiswaan ada beberapa yang berperan (1) Waka Kesiswaan, (2) Guru BK, (3) KTU, (4) Staf Kesiswaan, (Wali Kelas).

Tugas bidang kesiswaan itu sendiri antara lain : mengkoordinasi input siswa, proses hingga output.

Adapun Factor pendukung dalam bidang kesiswaan di SMK Ma'arif 4 Kebumen yaitu (1) SDM yang berkomitmen dimana semua warga sekolah harus sadar akan tugas dan tanggung jawabnya masing masing, dengan adanya warga sekolah yang berkomitmen akan menjadikan program tercapai dengan efektif dan efisien.(2) Kepemimpinan yang aktif, seorang pemimpin harus mampu melihat semua kondisi yang ada di sekolah termasuk dalam aktivitas siswa seperti kedisiplinan yang dilakukan siswa, pelanggaran yang dilakukan siswa dan sebagainya. (3) Sarpras yang lengkap dan memadai dimana jika sarpras lengkap dan memadai akan mempermudah warga sekolah dalam beraktivitas. (4) Prestasi siswa diraih di berbagai bidang, seperti lomba Tari yang belum lama ini diraih oleh siswi SMK Ma'arif 4 Kebumen dalam lomba Tari Tradisional Pelajar Tahun 2019 yang diselenggarakan oleh Dinas Kearsipan dan Perpustakaan Kabupaten Kebumen. Selain itu, prestasi di bidang Pencak Silat mendapat Juara 1 di Yogyakarta. Dukungan pembina masing masing memberikan reward yang meraih kejuaraan. (5) Guru BK yang berkualitas dibuktikan dengan memenuhi standar kualifikasi dan telah mengikuti berbagai pelatihan Guru BK Profesional seta memiliki kreatifitas yang tinggi supaya siswa tidak bosan.

Di dalam sekolah faktor penghambat sudah pasti terjadi, hal ini juga terjadi di SMK Ma'arif 4 Kebumen dimana kurangnya kesadaran dan tanggung jawab atas tugas yang telah diberikan oleh wakasek kesiswaan kepada anggotanya sehingga kurang efektif dan efisien. Kemudian sumber daya manusia yang kurang kompak dalam bekerja, seperti halnya dalam 
kebiasaan wakasek kesiswaan dan guru BK yang selalu menyambut siswanya di depan gerbang sebelum jam 07.10, penyambutan biasanya di lakukan dengan berjabat tangan langsung dengan siswa, mengamati siswa yang berpakaian tidak rapi, menggunakan sandal, tidak turun dari sepeda/motor ketika berjabat tangan dengan guru piket dan staf lainya yang menyambut. Penyambutan ini dilakukan dengan tujuan supaya wakasek kesiswaan dan guru BK lebih dekat dengan siswa dan juga mengetahui langsung tertib atau tidaknya siswa tersebut.

Namun dalam hal ini kenyataanya tidak semua pendidik dan tenaga kependidikan yang mempunyai kesadaran untuk ikut berpartisipasi dalam rutinitas tersebut, bahkan ada pendidik dan tenaga kependidikan yang kurang tertib dalam kebiasaan yang dilakukan oleh SMK Ma'arif 4 Kebumen pada pagi hari, seperti : turun dari motor/sepeda ketika di depan gerbang, berjabat tangan dengan penyambut siswa sesama lawan jenis, dan lain sebagainya. Sebaiknya dari kepala sekolah, pendidik dan tenaga kependidikan mencontohkan siswanya untuk melakukan budaya di SMK Ma'arif 4 kebumen ini, serta ikut andil dalam rutinitas tersebut supaya kekompakan dan keharmonisan tetap terjaga.

Dari rutinitas wakasek dan guru BK tersebut tidak sedikit menemukan siswa yang belum disiplin termasuk dalam berpakaian, menggunakan atribut yang lengkap, bersepatu dan lain sebagainya. Tidak sedikit pula siswa siswi yang masih terlambat dalam jam yang sudah di tentukan (07.00). Dari pemaparan tersebut terlihat bahwa wakasek kesiswaan dan staf kesiswaan lainya sangat berberan penting dalam pembentukan karakter siswa dan kebutuhan siswa lainya, utamanya guru BK yang mengatasi siswa langsung dalam bermasalah atau siswa yang membutuhkan bimbingan, namun disisi lain beberapa kendala dalam melaksanakan bimbingan konseling tersebut seperti tidak ada kejelasan dalam jam kelas, tidak ada papan bimbingan, keterbatasan sumber daya manusia sehingga mengakibatkan artikel kecil belum ada, dan banyaknya pekerjaan pada guru BK, serta jadwal bimbingan konseling belum teratur.

Dalam penanganan siswa bermasalah di SMK Ma'arif 4 Kebumen, ada 3 penanganan yang dilakukan oleh guru BK, yang pertama di beri pembinaan serta (SP I), yang ke dua di beri pembinaan (SP 2), dan yang terakhir (SP 3), jika SP 3 masih melanggar selanjutnya di tangani oleh Kepala Sekolah dan diadakan sidang kasus bersama orang tua siswa. 
Tabel 1. Jumlah Siswa Smk Ma'arif 4 Kebumen Tahun Pembelajaran 2019/2020

\begin{tabular}{|c|c|c|c|c|c|}
\hline \multirow{2}{*}{ NO } & \multirow{2}{*}{ KELAS } & \multirow{2}{*}{ WALI KELAS } & \multicolumn{2}{|c|}{ JUMLAH } & \multirow{2}{*}{ JUMLAH } \\
\hline & & & LK & PR & \\
\hline 1 & $\mathrm{X}$ TAV & Nurul Wahidah, S.Pd & 13 & 23 & 36 \\
\hline 2 & X TMI & Habib Amrulloh Yasin, S.Pd & 26 & 3 & 29 \\
\hline 3 & $\mathrm{X}$ TKRO A & Hidayani, S.Pd & 37 & 0 & 37 \\
\hline 4 & X TKRO B & Akhmad Sukron, S.Pd & 29 & 0 & 29 \\
\hline 5 & X PS & Moh. Mudakir, S.Pd.I & 0 & 12 & 12 \\
\hline \multicolumn{2}{|c|}{ JUMLAH } & & 105 & 38 & 143 \\
\hline 6 & XI TAV A & Nurul Laeliyah, S. HI & 8 & 26 & 34 \\
\hline 7 & XI TMI A & Eti Latifatun, S.Pd & 29 & 4 & 33 \\
\hline 8 & XI TMI B & Heni Sulistio, S. Pd & 36 & 0 & 36 \\
\hline 9 & XI TKRO A & Darwati, M.Pd & 33 & 0 & 33 \\
\hline 10 & XI TKRO B & Moh. Saechu, S. Pd & 32 & 0 & 32 \\
\hline 11 & XI TKRO C & Rahmat Fitri Purwanto, S. Pd & 33 & 0 & 33 \\
\hline 12 & XI PS & $\begin{array}{l}\text { Bintang Putra Nugraha, S. } \\
\text { Kom }\end{array}$ & 0 & 14 & 14 \\
\hline \multicolumn{2}{|c|}{ JUMLAH } & & 171 & 44 & 215 \\
\hline 13 & XII TAV A & Yuliani Widiastuti, S. Pd & 7 & 19 & 26 \\
\hline 14 & XII TAV B & Nova Eka Farastanti, S.Pd & 6 & 15 & 21 \\
\hline 15 & XII TMI A & Handi Yunus, S. Pd & 20 & 3 & 23 \\
\hline 16 & XII TMI B & Doni Rohmiyanto, S. Pd & 12 & 3 & 15 \\
\hline 17 & XII TKRO A & Eko Saputro, S. Pd & 29 & 0 & 29 \\
\hline 18 & XII TKRO B & Eko Purwanto, S. Pd & 25 & 5 & 30 \\
\hline 19 & XII TKRO C & $\begin{array}{l}\text { Alifia Octaviana Wulandari, } \\
\text { S. Pd }\end{array}$ & 30 & 0 & 30 \\
\hline 20 & XII TKRO D & Yulianti Maryam, S. Pd & 29 & 2 & 31 \\
\hline 21 & XII PS & Dra. Yuyun Rosulianti & 21 & 0 & 21 \\
\hline \multicolumn{2}{|c|}{ JUMLAH } & & 179 & 47 & 226 \\
\hline
\end{tabular}


Tabel 2. Komponen Program BK

\begin{tabular}{|c|c|c|}
\hline Komponen & $\begin{array}{l}\text { Cara Pemberian } \\
\text { Layanan }\end{array}$ & Strategi/Kegiatan/Kegiatan Layanan \\
\hline \multirow{6}{*}{ Layanan Dasar } & Langsung & Bimbingan Klasikal \\
\hline & & Bimbingan kelas besar/ Lintas Kelas \\
\hline & & Bimbingan Kelompok \\
\hline & \multirow{3}{*}{ Melalui Media } & $\begin{array}{l}\text { Pengembangan media bimbingan dan } \\
\text { konseling }\end{array}$ \\
\hline & & Papan bimbingan \\
\hline & & Leaflet \\
\hline \multirow{7}{*}{$\begin{array}{c}\text { Layanan Peminatan } \\
\text { dan Perencanaan } \\
\text { Individual }\end{array}$} & \multirow{7}{*}{ Langsung } & Bimbingan Klasikal \\
\hline & & Bimbingan Individual \\
\hline & & Bimbingan Kelompok \\
\hline & & Bimbingan Kelas Besar/ Lintas Kelas \\
\hline & & Bimbingan Kelompok \\
\hline & & Konsultasi \\
\hline & & Kolaborasi \\
\hline \multirow{9}{*}{ Layanan Responsif } & \multirow{7}{*}{ Langsung } & Konseling Individual \\
\hline & & Konseling Kelompok \\
\hline & & Konsultasi \\
\hline & & Konferensi Kasus \\
\hline & & Kunjungan Rumah \\
\hline & & Alih Tangan Kasus \\
\hline & & Advokasi \\
\hline & \multirow[b]{2}{*}{ Melali Media } & Konseling melalui elektronik \\
\hline & & $\begin{array}{l}\text { Kotak Masalah (Kotak Kebutuhan } \\
\text { Peserta didik/ Konseli) }\end{array}$ \\
\hline \multirow{6}{*}{ Dukungan Sistem } & \multirow{4}{*}{ Administrasi } & $\begin{array}{l}\text { Pelaksanaan dan Tindak lanjut } \\
\text { Assesment (termasuk kunjungan rumah) }\end{array}$ \\
\hline & & $\begin{array}{l}\text { Penyusunan dan pelaporan program } \\
\text { bimbingan dan konseling }\end{array}$ \\
\hline & & Evaluasi bimbingan dan Konseling \\
\hline & & $\begin{array}{l}\text { Pelaksanaan Administrasi dan } \\
\text { Mekanisme Bimbingan dan Konseling }\end{array}$ \\
\hline & \multirow{2}{*}{$\begin{array}{c}\text { Kegiatan Tambahan } \\
\text { dan Pengembangan } \\
\text { Keprofesian }\end{array}$} & $\begin{array}{l}\text { Kegiatan tambahan guru Bimbingan dan } \\
\text { Konseling atau Konselor }\end{array}$ \\
\hline & & Pengembangan \\
\hline
\end{tabular}




\begin{tabular}{|l|c|l|}
\hline Berkelanjutan & $\begin{array}{l}\text { berkelanjutan tambahan guru Bimbingan } \\
\text { dan Konseling atau Konselor }\end{array}$ \\
\hline
\end{tabular}




\section{Gambar 3. Mekanisme Kerja Bimbingan dan Konseling}

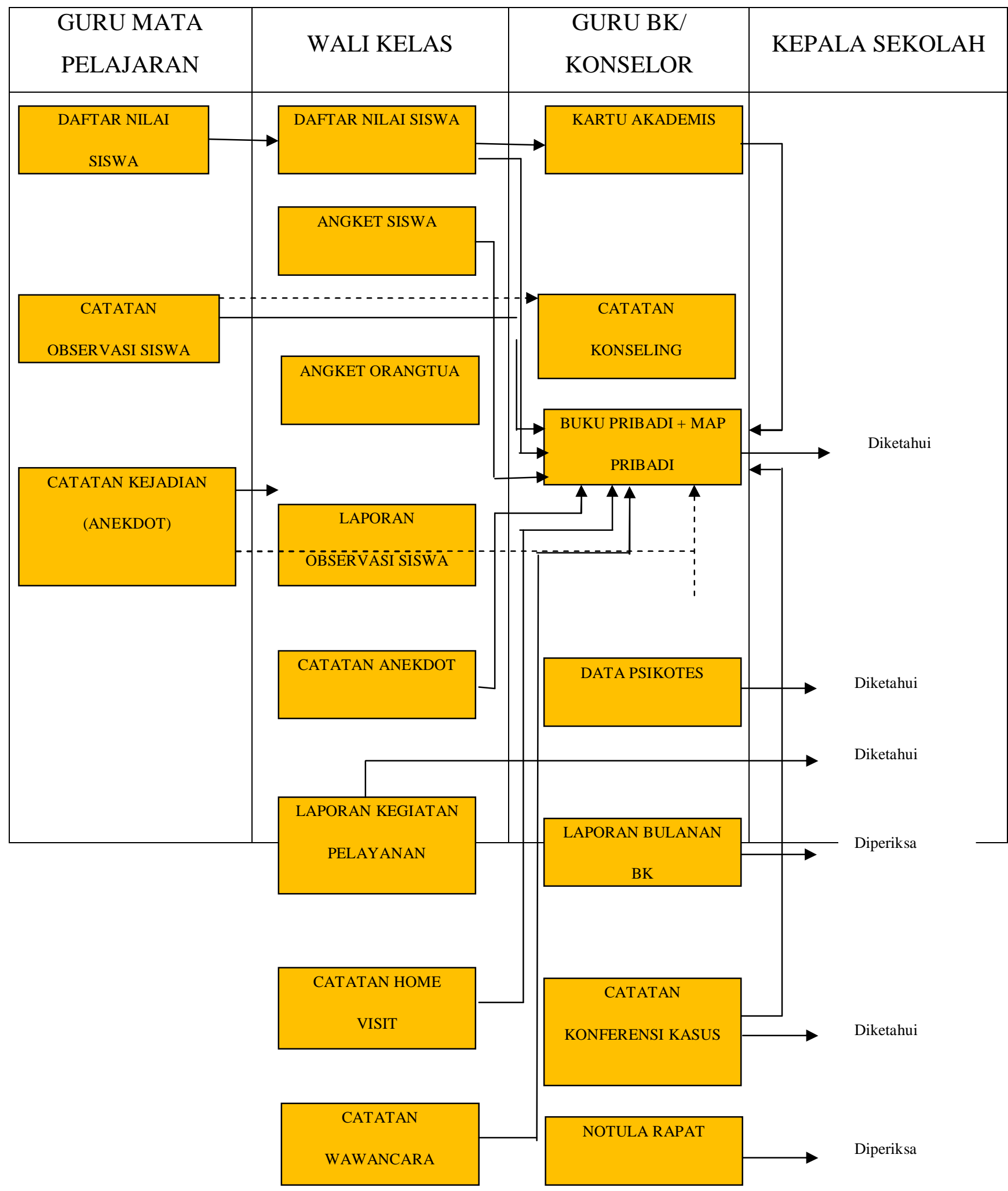




\section{b. Manajemen Pendidik dan Tenaga Kependidikan di SMK Ma'arif 4 Kebumen}

Tenaga kependidikan berdasarkan UU No. 20 tahun 2003 pasal 1, BAB 1 Ketentuan umum adalah anggota masyarakat yang mengabdikan diri dan diangkat untuk menunjang penyelenggaraan pendidikan.Dalam UU No. Tahun 2003 Pasal 39 ayat 1 tenaga kependidikan yaitu tenaga yang bertugas merencanakan dan melaksanakan administrasi, pengelolaan, pengembangan, pengawasan, dan pelayanan teknis untuk menunjang proses pendidikan pada satuan pendidikan.

Keadaan tenaga kependidikan di SMK Ma'arif 4 Kebumen berdasarkan arsip-arsip tata usaha sebanyak 22 orang dari jumlah tersebut diantaranya 15 tenaga kependidikan laki-laki dan 7 tenaga kependidikan perempuan.

\section{c. Deskripsi Tenaga Pendidik dan Kependidikan}

Tenaga pendidik dan kependidikan dalam proses Pendidikan memegang peran penting terutama dalam upaya untuk membentuk watak bangsa melalui pengembangan kepribadian dan nilai-nilai yang diinginkan. Jadi manajemen tenaga pendidik dan kependidikan adalah aktivitas yang harus dilakukan mulai dari tenaga pendidik dan kependidikan masuk ke dalam organisasi pendidikan sampai akhirnya berhenti.

a. Perencanaan Sumber Daya Manusia (SDM)

Perencanaan manajemen tenaga pendidik dan kependidikan adalah pengembangan dan strategi dan penyusunan tenaga pendidik dan kependidikan (Sumber Daya Manusia/SDM) yang komprehensif guna memenuhi kebutuhan organisasi di masa depan. Di SMK Ma'arif 4 Kebumen perencanaan tenaga kerja memperhatikan usulan dari waka kurikulum.Waka kurikulum mendata kebutuhan tenaga pendidik yang sedang dibutuhkan yang kemudian diinformasikan kepada personalia. dan kemudian pihak personalia langsung memanggil calon pelamar yang sudah melamar di SMK Ma'arif 4Kebumen.

b. Perekrutan

Perekrutan merupakan proses memilih tenaga kerja yang memenuhi syarat dan tepat sesuai dengan klasifikasi jabatan yang dibutuhkan. Di SMK Ma'arif 4 Kebumen yang terlibat dalam memilih tenaga kerja sesuai dengan kebutuhan adalah tugas waka kurikulum yang mendata kebutuhan tenaga pendidik dan KTU mendata kebutuhan tenaga kependidikan, dengan melihat 
berkas lamaran yang sudah diterima calon personil kemudian diseleksi secara administrasi sesuai dengan kriteria tenaga pendidik dan tenaga kependidikan oleh waka kurikulum dan KTU.

Menurut waka ketenagaan yaitu Bapak H. Muhamad Kowangid, M.Pd di SMK Ma'arif 4 Kebumen sekarang sangat mudah mencari guru dibandingkan dengan mencari muridnya karena di SMK Ma'arif 4 Kebumen ini calon pendidik dan tenaga kependidikan banyak yang menaruh surat lamarannya walaupun tidak adanya pengiklanan sedang dibutuhkannya pendidik dan tenaga kependidikan.

Adapun syarat yang ditetapkan dalam proses perekrutan untuk calon pendidik dan tenaga kependidikan di SMK Ma'arif 4 Kebumen yaitu beragama Islam, dapat membaca Al-Qur'an, ijazah pendidikan terakhir minimal S1, mampu mengoperasikan computer, bidang pendidikan sesuai dengan kompetensi yang dibutuhkan, diutamakan mempunyai pengalaman mengajar dibidangnya, sesuai dengan jurusan mata pelajaran yang dibutuhkan, apabila sekolah membutuhkan karena adanya jabatan yang kosong, siap bekerja di SMK Ma'arif 4 Kebumen sesuai dengan peraturan dan tata tertib Undang-Undang yang ada.

c. Seleksi

Seleksi adalah usaha yang dilakukan sekolah untuk memperoleh tenaga yang kualifikasi dan kompeten yang akan menjabat serta mengerjakan semua pekerjaan yang sesuai dengan kompetensinya. Dalam proses menyeleksi calon tenaga baru baik tenaga pendidik atau tenaga kependidikan di SMK Ma'arif 4 Kebumen dilakukan langsung oleh wakasek 1 (bidang kurikulum ) dan personalia. Calon tenaga baru di tes secara tertulis, tes praktek (micro teaching), kemudian tes wawancara yang dilaksanakan bersama komite sekolah. Setelah hasil tes selesai direkap dilaporkan kepada kepala sekolah untuk menentukan calon tenaga baru yang terpilih.

Bagi calon tenaga baru yang dinyatakan diterima, akan dilakukan pemanggilan untuk melengkapi perlengkapan administrasi dan mendapat informasi tentang tugas-tugas dari waka kurikulum dan KTU. Calon tenaga baru harus siap dan bersedia melaksanakan tugas di SMK Ma'arif 4 Kebumen setiap harinya.

\section{Penempatan}

Penempatan tenaga pendidik dan tenaga kependidikan di SMK Ma'arif 4 Kebumen sebagian besar sudah sesuai dengan latar belakang Pendidikan kecuali ada beberapa tenaga yang diangkat sebelum aturan yang terbaru dibuat.Penempatan tenaga pendidik dan tenaga 
kependidikan sesuai dengan kompetensinya atas usulan waka kurikulum dan kepala tata usaha kepada kepala sekolah serta waka personalia.

2. Pendidikan dan Pelatihan Pengembangan Guru dan Karyawan

Pendidikan dan pelatihan sebagai upaya dalam mengembangkan sumber daya manusia (SDM) terutama untuk mengembangkan kemampuan intelektual dan kepribadian manusia.Oleh karena itu untuk memperoleh hasil yang maksial dalam pengembangan pegawai diperlukan program pendidikan dan pelatihan yang sesuai dengan kompetensinya agar pegawai tersebut mengetahui tujuan pendidikan dan pelatihan yang dijalankan.Pengembangan potensi tenaga pendidik dan tenaga kependidikan dapat melalui seminar, workshop, musyawarah guru mata pelajaran (MGMP), Bimroh (bimbingan rohani) yang dilakukan setiap bulan sekali secara rutin, magang ke DU/DI dan lain-lain.Pendidikan dan pelatihan dapat dilaksanakan atas kemauan sendiri, perintah atau tugas dari sekolah, maupun panggilan dari pemerintah.

d. Pemberhentian Tenaga Pendidik dan Kependidikan

Di SMK Ma'arif 4Kebumen dalam pemberhentian tenaga pendidik dan tenaga kependidikan dikarenakan pension, berhenti atau mengundurkan diri, pindah tempat kerja, meninggal dunia, atau diberhentikan dengan tidak hormat.

Batas usia pension untuk tenaga pendidik umur 60 tahun dan tenaga kependidikan umur 55 tahun. Seorang tenaga pendidik dapat mengajukan perpanjangan pension maksimum sampai usia 65 tahun dan tenaga kependidikan dapat mengajukan perpanjangan maksimum 60 tahun.

Waka ketenagaan juga mengerjakan Data Pokok Pendidikan (DAPODIK) untuk guru, karyawan, dan siswa. Semua data guru dan karyawan di DAPODIK ynag nantinya akan menjadi penilaian dari pusat mengenai Pendidikan dan Latihan Profesi Guru (PLPG), Pengembangan Keprofesian Berkelanjutan (PKB), sertifikasi guru dan lain-lain.

Administrasi yang dikelola dalam pendidik dan tenaga kependidikan (PTK) yaitu file PTK seperti formulir PTK, Kartu Tanda Penduduk (KTP),Kartu Keluarga terbaru, Nomor Pokok Wajib Pajak (NPWP), Ijazah Sekkolah Dasar sampai dengan Pendidikan Terakhir, SK dari awal diangkat sampai dengan terakhir, SK Riwayat Gaji Berkala, SK Riwayat Jabatan Fungsional, SK Riwayat Jabatan Struktural, Sertifikat Sertifikasi, Sertifikat Nilai (TOEFL, TOEIC, UKBI, TPA, dan lainnya), sertifikat Penghargaan, Foto Copy rekening/penerima tunjangan beserta nominalnya dan tahun penerimaaan, SK/Kartu Kesejahteraan (Asuransi Kesejahteraan, dana Pensiun, 
Jamkesmas, Jamsostek, dan lainnya), Sertifikat DIKLAT, Foto copy NISN/KTM anak yang masih sekolah/kuliah, SK/Sertifikat/Kartu Keterangan tentang Penerima Beasiswa. File siswa seperti Ijazah SMP/MTS, SKH, AK, KK, NISN, KIP, KPS, SKTM, dan lain-lain. Data dari PTK dan siswa digunakan untuk pengisian Data Pokok Pendidikan (DAPODIK).Absen guru dan karyawan pada saat upacara hari senin yang bertujuan untuk melatih kedisiplinan guru dan karyawan dalam melaksanakan upacara.

Adapun administrasi yang dikelola dalam Kepala Tata Usaha (KTU), yaituAgenda surat keluar dan surat masuk, Buku ekspedisi, Buku notulen rapat, Surat izin cuti, Kumpulan surat keputusan (SK) pembagian tugas mengajar guru, Laporan kegiatan sekolah, Buku induk siswa, Presensi pendidik dan tenaga kependidikan dan rekapitulasinya, dan Dokumen penerimaan gaji.

\section{Gambar 3. Skema Manajemen Pendidik dan Tenaga Kependidikan}

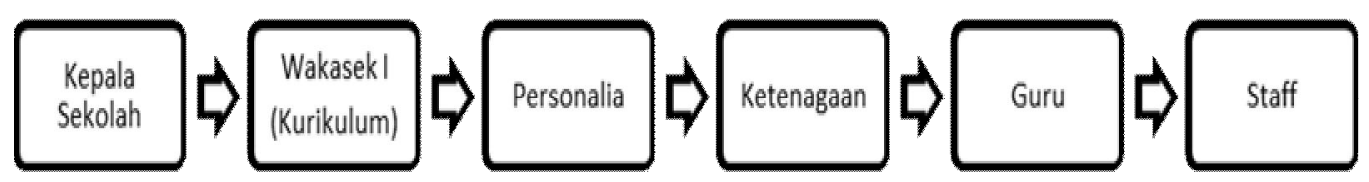

Dari bagan diatas dapat kita ketahui bahwa dalam pengelolaan pendidik dan tenaga kependidikan yaitu Dari kepala sekolah mengkoordinasikan kepada Waka Kurikulum kemudian Waka Kurikulum mengkoordinasikan kepada personalia, kemudian dari personalia mengkoordinasikan kepada ketenagaan, kemudian dari personalia mengkoordinasikan kepada guru, guru menginformasikan kepada staff.

\section{e. Faktor Pendukung}

Dalam sebuah lembaga pendidikan sudah pasti tidak lepas dari pendidik dan tenaga kependidikan yang profesional sebagai salah satu penunjang untuk tercapainya pendidikan yang bermutu. Seorang pendidik akan menjadi profesional apabila mempunyai pendidikan yang tinggi, karena tingkat pendidikan sangat mendukung terbentuknya kinerja yang profesional yang diharapkan oleh masyarakat untuk membentuk anak-anaknya menjadi anak yang mempunyai pengetahuan yang luas dan memiliki akhlak yang baik (berbakti kepada orang tua). Di SMK 
Ma'arif 4 Kebumen sendiri sudah memiliki pendidik dan tenaga kependidikan yang berpendidikan tinggi sesuai standar pendidikan sebagai salah satu faktor pendukung dalam bidang pendidik dan tenaga kependidikan di SMK Ma'arif 4 Kebumen yaitu semua guru sudah memenuhi standar kualifikasi pendidik yaitu dengan bergelar S1, terdapat $75 \%$ guru sudah bersertifikasi (sertifikat guru profesional).

\section{Faktor Penghambat}

Adanya faktor pendukung sudah pasti tidak terlepas dari faktor penghambat dalam sebuah lembaga pendidikan. adapun faktor penghambat dalam bidang pendidik dan tenaga kependidikan di SMK Ma'arif 4 Kebumen yaitu adanya guru yang berhalangan datang, kurang disiplinnya sebagian guru seperti datang tidak tepat waktu.

\section{Solusi dari Faktor Penghambat}

Faktor penghambat yang dialami di SMK Ma'arif 4 Kebumen menyebabkan sistem pelayanan dan pembelajaran menjadi kurang efektif dan kondusif. Dari faktor penghambat tersebut Bapak H. Muhamad Kowangid, M.Pd, selaku Waka Ketenagaan di SMK Ma'arif 4 Kebumen memberikan solusi untuk faktor penghambat yang terjadi pada manajemen pendidik dan tenaga pendidikan adalah memberikan teguran kepada pendidik dan tenaga pendidikan

\section{Manajemen Hubungan Industri}

Manajemen Hubungan Industri merupakan pengelolaan hubungan kerja yang dilakukan oleh pihak sekolah dengan dunia industri dalam mendidik peserta didiknya agar memiliki ketrampilan dan kesiapan kerja ke dunia industri. Bentuk hubungan kerja yang dilakukan adalah dengan menjalin kerjasama kemitraan dengan pihak industri.

Drs. Fatnan Sugiarto yang telah menjabat sebagai wakasek hubungan industri 2 tahun berjalan mengemukakan bahwa tugas utama wakasek hubin adalah (1) Kerjasama (2) Penyaluran Prakerin. Wakil kepala sekolah bidang hubungan industri dalam melaksanakan tugasnya dibantu oleh staf tata usaha. Meski demikian masih ada beberapa kegiatan wakil kepala sekolah bidang hubungan industri dalam periode ini yang belum sepenuhnya menguasai dalam bidang hubungan industri tersebut, terbukti dalam menjalankan aktifitas di bidang hubungan industri masih bekerja 
sama dengan penjabat wakil kepala sekolah bidang hubungan industri lama. Sehingga dalam hal tersebut menjadikan administrasi kurang lengkap.

\section{Gambar 4. Skema Manajemen Hubungan Industri}

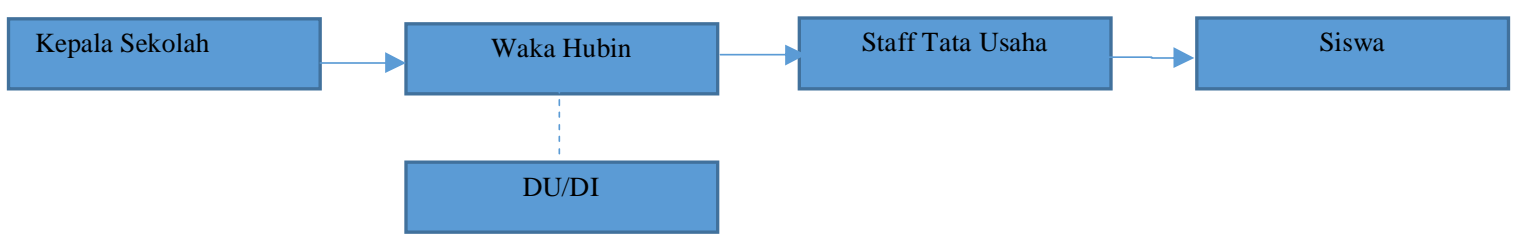

Pada tahap perencanaan, SMK Ma'arif 4 Kebumen bekerjasama melalui ikatan perjanjian (MoU) dengan DU/DI dalam menyelenggarakan program pelatihan dan pendidikan. Kerjasama ini terjalin secara berkesinambungan dan terus menerus agar peserta didik melakukan praktik secara bertahap.

Praktek kerja industri merupakan suatu bentuk pendidikan yang dilakukan oleh peserta didik langsung bekerja di dunia usaha/industri agar memiliki kompetensi yang sesuai dengan kebutuhan dan tuntutan dunia industri. Selain itu, peserta didik memperoleh pengalaman kerja sebagai bekal ketrampilan ketika terjun ke dunia kerja.

Adapun dokumen yang diperlukan dalam melaksanakan manajemen hubungan industri yaitu Buku Induk Daftar Perusahaan Prakerin dan Penyaluran kerja, MoU dan penyaluran Alumni

Faktor Pendukung pada bidang hubungan industri dari internal yaitu alat-alat memadai dan Guru yang kompeten. Sedangkan Faktor pendukung dari luar yaitu, bekerjasama dengan perusahaan bonafit, penyaluran prakerin, penyaluran kerjasama, dengan alumni. Selain factor pendukung, ada pula faktor Penghambat dalam bidang hubungan industri antara lain, alat atau sarana praktik yang belum memadai, ketimpangan yang cukup tinggi antara kurikulum sekolah dengan kurikulum di dunia kerja, produk siswa yang belum siap masuk dunia kerja, kurangnya kompetensi yang dimiliki oleh siswa sehingga berdampak pada kesiapan siswa dalam memasuki dunia kerja, guru yang kurang kompeten. 


\section{Kesimpulan}

Dari hasil riset di atas dapat disimpulkan bahwa manajemen pendidikan sangatlah penting di sebuah lembaga pendidikan, tanpa adanya manajemen pendidikan, lembaga pendidikan tidak akan berjalan. SMK Ma'arif 4 Kebumen menerapkan sistem manajemen ISO yaitu sebuah organisasi penjamin mutu pendidikan, konsep yang terencana dan terstruktur dimana masing masing bidang telah dibagi sesuai dengan bidangnya masing-masing dan teradministrasi.

Penyusunan kurikulum yang diterapkan adalah K13 yang disusun sesuai regulasi dan peraturan yang direkomendasikan Pengawas Sekolah. Di awal tahun Wakasek I Bidang Kurikulum, Bpk Nur Khotib, S.T membagi pembagian tugas kurikulum ke guru dan staff sehingga kurikulum berjalan dengan optimal. Penyusunan Silabus, RPP, Prota, Promes, disusun oleh masing-masing guru.

Manajemen kesiswaan merupakakan segala kegiatan yang berkaitan dengan siswa yakni mulai dari awal masuk sampai dengan siswa tamat, kegiatan kegiatan manajemen kesiswaan di SMK Ma'arif 4 Kebumen sudah tertata dengan baik, dilihat dari administrasi PPDB, buku kehadiran siswa, sampai dengan administrasi pengambilan ijazah.

Manajemen Pendidik dan Tenaga Kependidikan sudah tersusun dengan rapih, mulai dari perekrutan, seleksi serta penempatan calon pendidik dan tenaga kependidikan. Dalam seleksi calon pendidik dan tenaga kependidikan SMK Ma'arif 4 Kebumen ini lebih mengutamakan calon pendidik dan tenaga kependidikan yang berdomisili lebih dekat dengan sekolah, juga mengutamakan alumni dari sekolah SMK Ma'arif 4 Kebumen dengan alasan pihak sekolah sudah memahami kepribadian alumni tersebut.

Manajemen hubungan industri merupakan pengelolaan hubungan kerja yang dilakukan oleh pihak sekolah dengan dunia industri dalam mendidik peserta didiknya agar memiliki ketrampilan dan kesiapan kerja ke dunia industri. Kegiatan hubungan industri di SMK Ma'arif 4 Kebumen seperti, menjalin kerja sama dengan DUDI, penempatan prakerin, kunjungan industri dan penyaluran kerja.

Kepala sekolah mempunyai peranan sentral dalam dinamika kehidupan organisasi, dan sangat mempengaruhi kegiatan kegiatan suatu organisasi untuk menuju kepada penentuan /pencapaian tujuan. Kepala sekolah memiliki gaya kepemimpinan yang demokratis, memiliki pribadi yang ramah, disiplin, terbuka, rendah hati, religius dan sabar. Namun, masih terdapat 
beberapa pengelolaan yang belum optimal seperti: pengawasan dan kontrol secara langsung terhadap personalia sekolah sehingga komunikasi kurang intens. Rekomendasi, sekolah ini masih perlu meningkatkan dan menguatkan diri dalam aspek inovasi dan kreativitas terkait tuntutan dan kebutuhan zaman sekarang ini.

\section{Daftar Pustaka}

Agustinus, Hermino. 2014. Kepemimpinan Pendidikan di Era Globalisasi. Yogyakarta : Pustaka Pelajar.

Azwar, Saifuddin. 2010. Metode Penelitian. Yogyakarta: Pustaka Pelajar.

Daryanto. 2011. Kepala Sekolah sebagai Pemimpin Pembelajaran. Yogyakarta : Gava media

Eliyanto. 2018. Manajemen Sumber Daya Manusia Pendidikan. Yogyakarta: Program Studi Manajemen Pendidikan Islam Fakultas Ilmu Tarbiyah dan Keguruan Universitas Islam Negeri (UIN) Sunan Kalijaga.

Hidayat, Ara dan Imam Machali. 2012. Pengelolaan Pendidikan. Yogyakarta: Kaukaba.

Kholis, Nur. 2013. Manajemen Strategi Pendidikan: Formulasi, Implementasi, dan Pengawasan. Surabaya: UIN Sunan Ampel

Huda Miftahul. 2015. Penelitian Tindakan Kelas, Yogyakarta: Pustaka Pelajar.

Mulyasa. 2015. Manajemen Kepemimpinan Kepala Sekolah. Jakarta: PT Bumi Aksara.

Novianty, Djafri. 2017. Manajemen Kepemimpinan Kepala Sekolah. Yogyakarta : CV Budi Utama.

Rochaety, Eti. 2009. Sistem Informasi Manajemen Pendidikan. Jakarta: Bumi Aksara.

Sugiyono. 2014. Metode Penelitian kuantitatif Kualitatif dan R\&D. Bandung: Alfabeta.

Syaodih Sukmadinata, Nana, 2017. Metode Penelitian Pendidikan, Bandung: PT Remaja Rosdakarya. 